RICYDE. Revista Internacional de Ciencias del Deporte doi: $10.5232 /$ ricyde

Rev. int. cienc. deporte

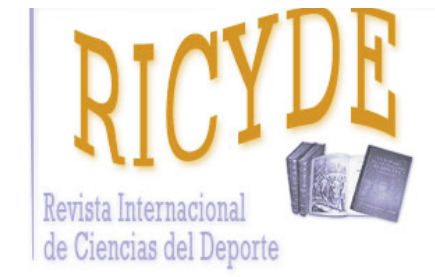

RICYDE. Revista Internacional de Ciencias del Deporte VOLUME XIV - YEAR XIV

Pages:84-95 ISSN:1885-3137

Issue: 51 - January - 2018

\title{
Analysis of shots in relation to the outcome in elite women's water polo matches Análisis de los lanzamientos en función del resultado en partidos de waterpolo femenino de élite
}

\author{
Cristina Menescardi ${ }^{1}$, Antonio Tessitore ${ }^{2}$, Isaac Estevan ${ }^{3}$, \\ Giancarlo Condello 2 \& Corrado Lupo 4
}

\begin{abstract}
1. Department of Motricity and Teaching of Physical Education, Universidad Católica de Valencia "San Vicente Mártir", Valencia, Spain
2. Department of Movement, Human and Health Sciences, University of Rome Foro Italico, Rome, Italy

3. Department of Teaching of Music, Visual and Corporal Expression, University of Valencia, Valencia, Spain

4. School of Exercise \& Sport Sciences (SUISM), Department of Medical Sciences, University of Torino, Turin, Italy
\end{abstract}

\begin{abstract}
The aim of the current study was to investigate the shot performance of elite female water polo players according to their match outcome during three international tournaments, the 2012 Olympic Games, 2013 and 2014 FINA World Leagues. Twenty-four official matches footage [2012 Summer Olympic Games, n=8; 2013 FINA World League, $n=8$ and 2014 FINA World League, $\mathrm{n}=8$ ] were obtained and analysed. The results showed that a similar playing style was used in both the 2012 and 2013 tournaments, independently of the outcome while in the 2014 FINA World League, winning teams performed more shots after displacement, more shots ending to zone 4 and scored more goals than losing ones (and fewer shots against posts), highlighting a greater ability to create team opportunities and score a goal. In addition, teams' behaviour changed over time: teams opted to perform more counterattacks and less power play situations. In addition to a more zonal defence, as time passes, probably to limit the play action of the opponent centre forward players. Teams also modified the type of shots performed to make them less predictable and to adapt them to each playing situation.
\end{abstract}

Key words: Observational analysis; technical indicators; tactical indicators, international female players.

\section{Resumen}

El objetivo del presente estudio fue investigar el rendimiento de los lanzamientos realizados por las jugadoras de élite de waterpolo en función de su resultado en el partido durante tres competiciones internacionales, los Juegos Olímpicos de 2012 y las FINA World Leagues de 2013 y 2014. Se obtuvieron y analizaron 24 partidos oficiales [Juegos Olímpicos de 2012, n=8; 2013 FINA World League, $n=8$ y 2014 FINA World League, $n=8$ ]. Los resultados mostraron un estilo de juego similar en los campeonatos de 2012 y 2013, independientemente del resultado obtenido, mientras que en la Liga Mundial de la FINA de 2014, los equipos ganadores realizaron más lanzamientos después de entradas, lanzamientos que terminaron en la zona 4 y marcaron más goles (y lanzaron menos a los postes) que los equipos perdedores, mostrando así una mayor habilidad del equipo para crear oportunidades y marcar gol. Además, el comportamiento de los equipos ha cambiado a lo largo del tiempo: los equipos optan por realizar un mayor número de contraataques y un menor número de jugadas de superioridad numérica. Así como el uso de una defensa más zonal conforme pasa el tiempo, probablemente para limitar la acción de juego de la jugadora boya oponente. Los equipos también han modificado el tipo de lanzamiento de las jugadoras buscando ser cada vez más variado y adaptado a las situaciones de juego para conseguir marcar gol.

Palabras clave: Análisis observacional; indicadores técnicos; indicadores tácticos; jugadoras internacionales.

Correspondence/correspondencia: Cristina Menescardi

Department of Motricity and Teaching of Physical Educaction, Universidad Católica de Valencia "San Vicente Mártir", Valencia, Spain Email: ca.menescardi@ucv.es 
Menescardi, C.; Tessitore, A.; Estevan, I.; Condello, G., \& Lupo, C. (2018). Analysis of shots in relation to the outcome in elite women's water polo matches. RICYDE. Revista internacional de ciencias del deporte, 51(14), 84-95. https://doi.org/10.5232/ricyde2018.05107

\section{Introduction}

$\mathrm{W}$ ater polo is an aquatic team sport that has been included in the Olympic Games programme, with the male competition since the second edition of Paris 1900, and the 27th edition of Sydney 2000 for the female competition. Over the years, there has been a continuous growth in the number of practitioners and teams, prompting researchers to study this discipline from different perspectives (Argudo, Arias, \& Ruiz, 2009), such as physiological (Botonis, Toubekis, \& Platanou, 2015), biomechanical (Stirn \& Strojnik 2006) and technical and tactical (Garcia, Argudo, \& Alonso, 2012; Gómez, DelaSerna, Lupo, \& Sampaio 2014, 2016; Lupo, Tessitore, Minganti, \& Capranica, 2010; Lupo, Condello, \& Tessitore, 2012a; Lupo, Minganti, Cortis, Perroni, Capranica, \& Tessitore, 2012b; Lupo, Condello, Capranica, \& Tessitore, 2014; Lupo, Capranica, Cugliari, Gómez, \& Tessitore 2015; Tucher et al, 2014) aspects. However, most of these studies has been carried out focussing on men's matches and despite a certain number of them has focused on women's water polo (Argudo, García, Alonso, \& Ruiz, 2007a,b; Escalante et al., 2011, 2012, 2013; Lupo, Tessitore, Minganti, King, Cortis, \& Capranica, 2011; Lupo et al., 2014; Takagi, Nishijima, Enomoto, \& Stewart, 2005). There is a lack of information about female water polo players' characteristics.

A water polo match is played by two teams of seven players (six outfield plus one goalkeeper) along four 8-minute clock-time quarters in a $25 \times 20 \mathrm{~m}$-court with a team's aim to score one goal more than its opponent. To discover the most effective scoring tactics, previous studies have focussed on the analysis of the shots performed during a match, including offensive and defensive final arrangements (Lupo et al., 2011, 2012a,b, 2014; Menescardi, 2017), player positions (Lupo et al., 2010; Özkol, Turunç, \& Dopsaj, 2013), type of shot (Argudo et al., 2007a,b, 2009; Lloret, 1998; Lupo et al., 2010, 2011, 2012a, 2014), zone where a shot ends up in the goal (Özkol et al., 2013) and the outcome of shots (Escalante et al., 2013). The revision of the water polo literature shows that shot analysis has been carried out on different parameters, but in separated studies, so there is currently no study covering all these variables to describe, in detail, the tactics used by teams.

Recently, the mentioned technical and tactical variables have been used to describe water polo shot performance in relation to the match outcome (e.g., Lupo et al., 2011) and during different tournaments (Lupo et al., 2010). Different patterns in the origin of the shot; the type of shot according to the condition of winner or loser; in addition to different playing situations and player positions between tournaments were reported (Lupo et al., 2010, 2011). Indeed, analysis of the winner/loser condition increases understanding of the winners' playing styles in a specific tournament, allowing the coaches to reproduce similar playing strategies in trainings. No study analysing the shots considering both conditions (match outcome and tournament) has been conducted to show whether differences are based on the level of competitors or the tactics chosen by players as time passes.

Therefore, the aim of this study was to investigate the shot performance of elite female water polo players using eight variables (play situation, offensive arrangement, defensive arrangement, goalkeeper position, player position, type of shot, goal zone, and outcome) and match status (winner or loser) during three international women tournaments (i.e., the 2012 Olympic Games, 2013 FINA World League, and 2014 FINA World League). It was hypothesized that examining the match outcome and tournament effect of women's water polo matches would increase the relevance and applicability of results for coaches. 
Menescardi, C.; Tessitore, A.; Estevan, I.; Condello, G., \& Lupo, C. (2018). Analysis of shots in relation to the outcome in elite women's water polo matches. RICYDE. Revista internacional de ciencias del deporte, 51(14), 84-95. https://doi.org/10.5232/ricyde2018.05107

\section{Method}

\section{Subjects}

A total amount of ninety-six quarters from twenty-four official matches footage [2012 Summer Olympic Games (London, UK): n=8; 2013 FINA World League (Beijing, China): $\mathrm{n}=8$ and 2014 FINA World League (Kunshan, China): $\mathrm{n}=8$ ] were obtained from public channel sites and analysed. The top eight teams in the world participated in the knockout stage (quarterfinal, semi-final, and final matches) of Olympic and World League tournaments.

\section{Procedures}

The Technical and tactical variables related to the analysis of shots were: (1) Play Situations; (2) Offensive Arrangements; (3) Defensive Arrangements; (4) Goalkeeper positions; (5) Player position; (6) Type of shot; (7) Zone of the goal were the shot ends, and (8) Outcome. All these variables were analysed according to the match outcome (winner or loser) in each bout (Table 1).

Table 1. Observational tool.

\begin{tabular}{|c|c|c|}
\hline Criteria & Categories & Descriptions \\
\hline \multirow[t]{4}{*}{ Play situation } & Even & $\begin{array}{l}\text { Even situations are those in which the number of offensive and } \\
\text { defensive players is equal (six vs. six) }\end{array}$ \\
\hline & Power play & $\begin{array}{l}\text { Uneven situation caused by the exclusion of players during } 20 \mathrm{~s} \\
\text { counter-attacks and transitions (five vs. six) }\end{array}$ \\
\hline & Transition & $\begin{array}{l}\text { Uneven situation where an offensive player is playing away from the } \\
\text { zone of defensive arrangement and the other offensive players }\end{array}$ \\
\hline & Counter-attack & $\begin{array}{l}\text { Uneven situation characterized by a rapid transition, strategically } \\
\text { occupying free space to create numerical superiority }\end{array}$ \\
\hline \multirow[t]{3}{*}{$\begin{array}{c}\text { Offensive } \\
\text { arrangement }\end{array}$} & $3: 3$ & $\begin{array}{l}\text { The } 3: 3 \text { offensive arrangements are those in which three players are } \\
\text { disposed along the two-metre line and the three remaining players are } \\
\text { at the five-metre line }\end{array}$ \\
\hline & $4: 2$ & $\begin{array}{l}\text { The } 4: 2 \text { offensive arrangement is when four players are arranged } \\
\text { along the two-metre line and the other two players are at the five- } \\
\text { metre line }\end{array}$ \\
\hline & Other & Offensive arrangement that does not fit on the previous classification \\
\hline \multirow[t]{8}{*}{$\begin{array}{c}\text { Defensive } \\
\text { arrangement }\end{array}$} & Pressing & $\begin{array}{l}\text { Pressing defence is characterized as aggressive because players are } \\
\text { face-to-face with the opponent trying to steal the ball }\end{array}$ \\
\hline & Zones $1-2$ & $\begin{array}{l}\text { System characterized by a double defence on the centre forward on } \\
\text { the right side of the court }\end{array}$ \\
\hline & Zones 2-3-4 & $\begin{array}{l}\text { System characterized by a double defence on the centre forward by } \\
\text { offensive players } 2,3 \text { and } 4 \text { depending on where the ball is located in } \\
\text { the court, that is, the centre forward is marked by the defender on the } \\
\text { opposite side of where the ball is in the court }\end{array}$ \\
\hline & Zones 4-5 & $\begin{array}{l}\text { System characterized by a double defence on the centre forward on } \\
\text { the left side of the court }\end{array}$ \\
\hline & $\mathrm{M}$ & $\begin{array}{l}\text { System characterized by a double defence on the centre forward } \\
\text { performed by the centre forward's opponent }\end{array}$ \\
\hline & Cluster & $\begin{array}{l}\text { Defensive tactical system of man-up situations where players are } \\
\text { placed in front of the opposite goal, all raising their arms at once }\end{array}$ \\
\hline & Anticipation & $\begin{array}{l}\text { Defensive tactical system of man-up situations where defenders are } \\
\text { placed among players in a dynamic situation to try to steal the ball }\end{array}$ \\
\hline & Other & Defensive arrangement that does not fit on the previous classification \\
\hline Type of shot & Drive & $\begin{array}{l}\text { Powerful and direct shot performed from the arm position, which is } \\
\text { executed by translating the arm from back to front, leaving the ball } \\
\text { out after the wrist flexion, with the elbow extended anteriorly and } \\
\text { parallel to the surface of the water; normally, the shot has a straight } \\
\text { path parallel to the water sheet }\end{array}$ \\
\hline
\end{tabular}


Menescardi, C.; Tessitore, A.; Estevan, I.; Condello, G., \& Lupo, C. (2018). Analysis of shots in relation to the outcome in elite women's water polo matches. RICYDE. Revista internacional de ciencias del deporte, 51(14), 84-95. https://doi.org/10.5232/ricyde2018.05107

\begin{tabular}{|c|c|c|}
\hline & With bounce & $\begin{array}{l}\text { Powerful shot into the water plate, with the aim that the ball dribbles } \\
\text { on the surface of the water and changes its trajectory, thereby causing } \\
\text { confusion for the goalkeeper or the goalkeeper of the opposite } \\
\text { equipment }\end{array}$ \\
\hline & Off the water & $\begin{array}{l}\text { Characteristic shot of the centre forward, in which they do not catch } \\
\text { the ball, but controls and projects the ball of the player by means of a } \\
\text { lower grip, with a circular movement, from the water to the opposite } \\
\text { goal }\end{array}$ \\
\hline & Dove & $\begin{array}{l}\text { Shot characterized by being less powerful, which creates a parabola } \\
\text { that passes over the defending players, making it impossible to block; } \\
\text { it is normally directed to the higher areas of the goal }\end{array}$ \\
\hline & Back & $\begin{array}{l}\text { Characteristic shot of the centre forward, located from the back to the } \\
\text { goal, in which the ball is gripped by its superior part or with the } \\
\text { forearm, and where a rapid pronation of the hand directs the ball } \\
\text { towards the goal }\end{array}$ \\
\hline & Other & Other type of shot that is not considered on the previous classification \\
\hline \multirow[t]{6}{*}{ Player position } & $\mathrm{P} 1$ & Left-handed wing located on the $2 \mathrm{~m}$ line \\
\hline & $\mathrm{P} 2$ & Left-handed flat or lateral located on the $5 \mathrm{~m}$ line in front of the posts \\
\hline & P3 & Centre or point located in a central position at around the $6 \mathrm{~m}$ line \\
\hline & P4 & $\begin{array}{l}\text { Right-handed flat or lateral located on the } 5 \mathrm{~m} \text { line in front of the } \\
\text { posts }\end{array}$ \\
\hline & P5 & Right-handed wing located on the $2 \mathrm{~m}$ line \\
\hline & P6 & Centre forward \\
\hline \multirow[t]{7}{*}{ Goal zone } & Z1 & Upper-right zone of the goal \\
\hline & $\mathrm{Z2}$ & Lower-right zone of the goal \\
\hline & $\mathrm{Z3}$ & Lower-centre zone of the goal \\
\hline & Z4 & Lower-left zone of the goal \\
\hline & $\mathrm{Z5}$ & Upper-left zone of the goal \\
\hline & Z6 & Upper-centre zone of the goal \\
\hline & Other & $\begin{array}{l}\text { Shot that has been blocked but where the ball's trajectory could not } \\
\text { be observed }\end{array}$ \\
\hline \multirow[t]{5}{*}{ Outcome } & Goal & $\begin{array}{l}\text { Shot that is well aimed at the opposing goal (inside the posts), } \\
\text { resulting in an increased score for the marker itself }\end{array}$ \\
\hline & Stopped & Stopped by the goalkeeper \\
\hline & Blocked & Blocked by defensive players \\
\hline & Posts & Badly aimed ball, which hits the posts or crossbar of the opposite goal \\
\hline & Outside & Badly aimed ball, outside the opposing goal \\
\hline
\end{tabular}

Observational analysis of official videos were made by only one experienced observer to avoid an intra-observers disagreement (Lupo et al., 2009, 2011) though a specific and validated software for observational studies in sport field (HOISAN) (Hernández-Mendo, López-López, Castellano, Morales, \& Pastrana, 2012). To assess the test-retest reliability before the study, the observer scored a match twice, separated by 15 days, and quantifying in terms of reliabity (kappa index) reporting an agreement of .88 , above of the minimum acceptable (Camerino, Chaverri, Anguera, \& Jonsson, 2012).

\section{Data Analysis}

Descriptive statistics included means and standard deviations for each dependent variable were calculated. A previous Kolmogorov-Smirnov test was carried out to determine the use of non-parametric analysis $(p<.05)$. Kruskall Wallis test followed by Mann Whitney U test for pairwise comparisons were used to assess differences between outcomes and tournaments. Statistical analyses were conducted using a SPSS package v.20 (Institute Inc., Cary, NC) with a criterion for significance set at $p<.05$. 
Menescardi, C.; Tessitore, A.; Estevan, I.; Condello, G., \& Lupo, C. (2018). Analysis of shots in relation to the outcome in elite women's water polo matches. RICYDE. Revista internacional de ciencias del deporte, 51(14), 84-95. https://doi.org/10.5232/ricyde2018.05107

\section{Results}

Table 2 presents the descriptive and effect results for all variables, on a quarter-by-quarter basis, in relation to match outcome and tournament.

Analysis by match outcome (winners vs. losers)

Differences emerged in the 2014 FINA World League (WL 2014) for displacements and other shot variables: there were higher values in the winning teams than the losing ones. Regarding the goal zone, differences between winners and losers were found in the 2013 FINA World League (WL 2013) and WL 2014: losing teams shot more than winners to Z3 and Z4, respectively. Finally, in WL 2014, differences between the winners and losers emerged for number of goals (higher for the winning teams) and number of shots against posts (lower for the winning teams).

\section{Comparison of winning teams between tournaments}

Pairwise comparisons showed that, during power play, more shots were performed in the 2012 Olympic Games than in the later tournaments $(p=.01 ; p=.04$, respectively for WL 2013 and 2014). Conversely, during counterattacks, more shots were performed in WL 2014 than in $2012(p<.01)$. In other offensive arrangements, fewer shots were performed in the 2012 Olympic Games than in the other tournaments $(p=.01 ; p<.01$, respectively for WL 2013 and 2014). Considering the shots performed in relation to the opponents' defensive arrangements, more shots were performed within defensive zone 1-2 in the 2012 Olympic Games than in the World League tournaments $(p=.01 ; p<.01$, respectively for WL 2013 and 2014), whereas the opposite trend emerged for the shots performed during zone 2-3-4 defence (with respect to WL 2013, $p<.01$; with respect to WL 2014, $p<.01$ ). For the same parameter, a difference emerged between WL 2013 and WL $2014(p=.02)$. During other opponents' defensive arrangements, more shots were performed in the World League tournaments than in the 2012 Olympic Games $(p=.04 ; p<.01$, respectively), and more shots were performed in WL 2013 than in WL $2014(p=.02)$. A higher number of shots with a bounce were performed in the 2012 and 2013 tournaments than in WL $2014(p<.01 ; p<.01$, respectively). In addition, more shots from P5 were performed in WL 2013 than in the 2012 Olympic Games $(p<.01)$. In WL 2014, more shots ended in Z4 than in the 2012 and 2013 tournaments $(p<.01 ; p=.04$, respectively). Finally, in WL 2014, fewer shots hit the posts than in the 2012 and 2013 tournaments ( $p<.02 ; p=.02$, respectively).

\section{Comparison of losing teams between tournaments}

More shots were performed during the 2012 Olympic Games than in the other tournaments in power play (with respect to 2013, $p=.04$, and 2014, $p<.01$ ) and pressing defence situations (with respect to 2013, $p=.03$ and 2014, $p<.02$ ). However, fewer shots were performed during a zone 2-3-4 defence in the 2012 tournament than in WL $2013(p<.01)$ and WL $2014(p<.01)$. Fewer shots during a zone $4-5$ defensive arrangement were performed in WL 2014 than in the 2012 Olympic Games $(p=.02)$. Considering the type of shot, more shots with a bounce were performed in the 2012 and 2013 tournaments than in WL 2014 ( $p=.01 ; p$ $=.04$, respectively). Finally, considering the zones where the shot ended, there were more shots to Z3 in WL 2013 than in WL $2014(p=.01)$, fewer to Z5 in the 2012 Olympic Games than WL $2014(p=.01)$, and more shots to Z6 in the 2012 tournament than in the 2013 and 2014 tournaments $(p<.01 ; p<.01$, respectively). 
Menescardi, C.; Tessitore, A.; Estevan, I.; Condello, G., \& Lupo, C. (2018). Analysis of shots in relation to the outcome in elite women's water polo matches. RICYDE. Revista internacional de ciencias del deporte, 51(14), 84-95. https://doi.org/10.5232/ricyde2018.05107

Table 2. Means, standard deviations and comparisons of each technical and tactical parameter, and differences $(p<.05)$ between water polo tournaments (i.e., 2012 Olympic Games, 2013 and 2014 FINA World Leagues) and match outcomes (i.e., Winners, Losers).

\begin{tabular}{|c|c|c|c|c|c|c|c|c|c|c|c|c|}
\hline & & \multicolumn{2}{|c|}{2012} & \multirow{2}{*}{$\begin{array}{l}U \\
p\end{array}$} & \multicolumn{2}{|c|}{2013} & \multirow{2}{*}{$\frac{U}{p}$} & \multicolumn{2}{|c|}{2014} & \multirow{2}{*}{$\frac{U}{p}$} & \multirow{2}{*}{$\frac{\chi^{2} \text { Win. }}{p}$} & \multirow{2}{*}{$\frac{\chi^{2} \operatorname{Los} .}{p}$} \\
\hline & & Winner & Loser & & Winner & Loser & & Winner & Loser & & & \\
\hline \multirow{4}{*}{$\begin{array}{c}\text { Play } \\
\text { situation }\end{array}$} & Power play & $2.31 \pm 1.40 \mathrm{ab}$ & $2.41 \pm 1.24 \mathrm{~cd}$ & .69 & $1.41 \pm 1.10$ & $1.69 \pm 1.38$ & .44 & $1.63 \pm 1.10$ & $1.50 \pm 1.16$ & .49 & .03 & .01 \\
\hline & Even & $3.81 \pm 1.75$ & $3.66 \pm 1.66$ & .81 & $4.88 \pm 1.98$ & $4.44 \pm 2.27$ & .33 & $4.31 \pm 2.19$ & $4.38 \pm 1.77$ & .78 & .12 & .36 \\
\hline & Counterattack & $0.22 \pm 0.49 b$ & $0.50 \pm 0.98$ & .31 & $0.44 \pm 0.56$ & $0.63 \pm 1.04$ & .96 & $0.72 \pm 0.85$ & $0.53 \pm 0.62$ & .49 & .02 & .53 \\
\hline & Transition & $0.13 \pm 0.34$ & $0.09 \pm 0.30$ & .69 & $0.38 \pm 0.55$ & $0.28 \pm 0.58$ & .33 & $0.19 \pm 0.47$ & $0.22 \pm 0.42$ & .57 & .07 & .31 \\
\hline \multirow{3}{*}{$\begin{array}{c}\text { Offensive } \\
\text { arrangement }\end{array}$} & $3: 3$ & $3.69 \pm 1.71$ & $3.59 \pm 1.90$ & .91 & $4.44 \pm 2.05$ & $4.28 \pm 2.11$ & .83 & $3.91 \pm 1.84$ & $3.84 \pm 1.61$ & .93 & .31 & .41 \\
\hline & $4: 2$ & $2.31 \pm 1.53$ & $2.41 \pm 1.39$ & .70 & $1.78 \pm 1.21$ & $1.88 \pm 1.64$ & .92 & $1.81 \pm 1.23$ & $1.75 \pm 1.16$ & .80 & .38 & .13 \\
\hline & Other & $0.47 \pm 0.95 \mathrm{ab}$ & $0.66 \pm 1.04$ & .53 & $0.88 \pm 0.83$ & $0.88 \pm 1.24$ & .44 & $1.13 \pm 1.04$ & $1.03 \pm .90$ & .81 & .01 & .11 \\
\hline \multirow{8}{*}{$\begin{array}{c}\text { Defensive } \\
\text { arrangement }\end{array}$} & Pressing & $1.09 \pm 1.09$ & $1.44 \pm 0.84 \mathrm{~cd}$ & .14 & $0.69 \pm 0.64$ & $1.00 \pm 1.08$ & .42 & $0.72 \pm 0.85$ & $1.00 \pm 1.02$ & .26 & .30 & .04 \\
\hline & Zone 1-2 & $0.44 \pm 0.56 \mathrm{ab}$ & $0.34 \pm 0.60$ & .37 & $0.16 \pm 0.45$ & $0.28 \pm 0.46$ & .15 & $0.09 \pm 0.30$ & $0.16 \pm 0.37$ & .45 & .00 & .37 \\
\hline & Zone 2-3-4 & $0.88 \pm 0.94 \mathrm{ab}$ & $1.09 \pm 1.12 \mathrm{~cd}$ & .50 & $3.06 \pm 1.90 \mathrm{~b}$ & $2.34 \pm 1.72$ & .13 & $1.97 \pm 1.62$ & $2.16 \pm 1.39$ & .58 & .00 & .00 \\
\hline & Zone 4-5 & $0.28 \pm 0.63$ & $0.25 \pm 0.51 \mathrm{~d}$ & .87 & $0.06 \pm 0.25$ & $0.06 \pm 0.25$ & 1.00 & $0.06 \pm 0.25$ & $0.03 \pm 0.18$ & .56 & .14 & .03 \\
\hline & $\mathrm{M}$ & $0.56 \pm 0.95$ & $0.31 \pm 0.64$ & .31 & $0.53 \pm 1.02$ & $0.53 \pm 0.88$ & .71 & $0.44 \pm 0.76$ & $0.34 \pm 0.55$ & .86 & .90 & .61 \\
\hline & Cluster & $2.13 \pm 1.50$ & $2.06 \pm 1.39$ & .97 & $1.31 \pm 1.09$ & $1.59 \pm 1.34$ & .45 & $1.44 \pm 1.05$ & $1.34 \pm 1.15$ & .50 & .06 & .09 \\
\hline & Anticipation & $0.13 \pm 0.34$ & $0.19 \pm 0.47$ & .69 & $0.09 \pm 0.30$ & $0.00 \pm 0.00$ & .08 & $0.13 \pm 0.55$ & $0.13 \pm 0.34$ & .43 & .72 & .08 \\
\hline & Other & $0.97 \pm 1.43 \mathrm{ab}$ & $0.97 \pm 1.15$ & .81 & $1.19 \pm 0.82 b$ & $1.22 \pm 1.29$ & .68 & $2.00 \pm 1.46$ & $1.47 \pm 1.14$ & .17 & .00 & .16 \\
\hline \multirow{3}{*}{$\begin{array}{l}\text { Goalkeeper } \\
\text { position }\end{array}$} & Right & $0.75 \pm 0.88$ & $0.94 \pm 1.05$ & .55 & $0.91 \pm 1.00$ & $1.00 \pm 0.88$ & .55 & $0.94 \pm 1.19$ & $0.91 \pm 1.15$ & .93 & .85 & .69 \\
\hline & Left & $0.63 \pm 0.94$ & $0.59 \pm 0.61$ & .60 & $0.94 \pm 0.91$ & $0.81 \pm 0.90$ & .55 & $0.91 \pm 1.03$ & $0.72 \pm 0.92$ & .44 & .22 & .70 \\
\hline & Centred & $5.09 \pm 2.12$ & $5.13 \pm 2.01$ & .88 & $5.25 \pm 1.90$ & $5.22 \pm 1.62$ & .74 & $5.00 \pm 2.29$ & $5.00 \pm 1.78$ & .92 & .80 & .87 \\
\hline \multirow{4}{*}{$\begin{array}{l}\text { Previous } \\
\text { action }\end{array}$} & Pass & $5.72 \pm 1.94$ & $5.63 \pm 1.62$ & .88 & $6.19 \pm 2.13$ & $6.31 \pm 1.80$ & .77 & $5.78 \pm 2.07$ & $5.69 \pm 1.86$ & .86 & .57 & .24 \\
\hline & Fault & $0.22 \pm 0.49$ & $0.53 \pm 0.76$ & .07 & $0.47 \pm 0.88$ & $0.31 \pm 0.47$ & .95 & $0.38 \pm 0.61$ & $0.66 \pm 0.79$ & .12 & .47 & .21 \\
\hline & Displacement & $0.38 \pm 0.75$ & $0.41 \pm 0.67$ & .64 & $0.34 \pm 0.48$ & $0.34 \pm 0.65$ & .60 & $0.63 \pm 0.79 *$ & $0.25 \pm 0.51$ & .03 & .19 & .65 \\
\hline & Shot & $0.16 \pm 0.57$ & $0.09 \pm 0.30$ & .97 & $0.09 \pm 0.30$ & $0.06 \pm 0.25$ & .64 & $0.06 \pm 0.25$ & $0.03 \pm 0.18$ & .56 & .87 & .59 \\
\hline \multirow{4}{*}{$\begin{array}{l}\text { Type of } \\
\text { shot }\end{array}$} & Drive & $3.78 \pm 1.88$ & $4.22 \pm 1.81$ & .26 & $3.97 \pm 2.07$ & $4.53 \pm 2.14$ & .23 & $4.69 \pm 1.93$ & $4.88 \pm 1.43$ & .32 & .21 & .33 \\
\hline & Bounce & $1.50 \pm 1.34 \mathrm{~b}$ & $1.50 \pm 1.65 \mathrm{~d}$ & .69 & $1.47 \pm 1.46 \mathrm{~b}$ & $1.13 \pm 1.21 \mathrm{~d}$ & .40 & $0.41 \pm 0.61$ & $0.59 \pm 0.87$ & .55 & .00 & .03 \\
\hline & Sharp & $0.19 \pm 0.47$ & $0.25 \pm 0.67$ & .95 & $0.25 \pm 0.44$ & $0.31 \pm 0.64$ & .94 & $0.41 \pm 0.67$ & $0.19 \pm 0.40$ & .19 & .31 & .80 \\
\hline & Dove & $0.53 \pm 0.57$ & $0.44 \pm 0.56$ & .47 & $0.81 \pm 1.00$ & $0.47 \pm 0.67$ & .21 & $0.50 \pm 0.72$ & $0.63 \pm 0.71$ & .40 & .48 & .51 \\
\hline
\end{tabular}


Menescardi, C.; Tessitore, A.; Estevan, I.; Condello, G., \& Lupo, C. (2018). Analysis of shots in relation to the outcome in elite women's water polo matches. RICYDE. Revista internacional de ciencias del deporte, 51(14), 84-95. https://doi.org/10.5232/ricyde2018.05107

\begin{tabular}{|c|c|c|c|c|c|c|c|c|c|c|c|c|}
\hline & Back & $0.28 \pm 0.63$ & $0.19 \pm 0.59$ & .34 & $0.16 \pm 0.37$ & $0.25 \pm 0.51$ & .49 & $0.25 \pm 0.51$ & $0.16 \pm 0.37$ & .49 & .74 & .60 \\
\hline & Other & $0.19 \pm 0.59$ & $0.06 \pm 0.25$ & .38 & $0.44 \pm 0.84$ & $0.34 \pm 0.83$ & .67 & $0.59 \pm 0.87 *$ & $0.19 \pm 0.47$ & .04 & .07 & .19 \\
\hline \multirow{7}{*}{$\begin{array}{c}\text { Player } \\
\text { position }\end{array}$} & $\mathrm{P} 1$ & $0.78 \pm 0.87$ & $0.91 \pm 0.96$ & .65 & $0.69 \pm 0.82$ & $1.22 \pm 1.21$ & .09 & $0.69 \pm 0.90$ & $0.81 \pm 1.03$ & .70 & .84 & .35 \\
\hline & $\mathrm{P} 2$ & $1.59 \pm 1.32$ & $1.72 \pm 1.42$ & .74 & $1.50 \pm 1.16$ & $1.75 \pm 1.22$ & .40 & $1.38 \pm 1.21$ & $1.69 \pm 1.06$ & .27 & .83 & .98 \\
\hline & $\mathrm{P} 3$ & $1.44 \pm 1.01$ & $1.44 \pm 1.37$ & .75 & $1.59 \pm 1.39$ & $1.13 \pm 1.10$ & .19 & $1.38 \pm 1.04$ & $1.41 \pm 1.21$ & .99 & .90 & .56 \\
\hline & $\mathrm{P} 4$ & $0.94 \pm 0.80$ & $1.34 \pm 1.31$ & .29 & $1.25 \pm 1.08$ & $1.16 \pm 0.95$ & .82 & $1.03 \pm 1.03$ & $1.25 \pm 1.19$ & .50 & .57 & .93 \\
\hline & P5 & $0.78 \pm 1.18 \mathrm{a}$ & $0.56 \pm 0.84$ & .59 & $1.25 \pm 0.84$ & $1.03 \pm 1.00$ & .27 & $1.19 \pm 1.28$ & $0.81 \pm 0.97$ & .20 & .02 & .12 \\
\hline & P6 & $0.84 \pm 1.19$ & $0.66 \pm 0.87$ & .81 & $0.75 \pm 0.84$ & $0.75 \pm 0.80$ & .94 & $1.19 \pm 1.15$ & $0.63 \pm 0.66$ & .06 & .24 & .79 \\
\hline & Goalkeeper & $0.09 \pm 0.30$ & $0.00 \pm 0.00$ & .08 & $0.06 \pm 0.25$ & $0.00 \pm 0.00$ & .15 & $0.00 \pm 0.00$ & $0.03 \pm 0.18$ & .32 & .23 & .37 \\
\hline \multirow{7}{*}{ Goal zone } & $\mathrm{Z} 1$ & $1.34 \pm 1.18$ & $1.00 \pm 1.02$ & .22 & $1.41 \pm 1.13$ & $1.47 \pm 1.27$ & .90 & $1.22 \pm 1.39$ & $1.38 \pm 1.29$ & .47 & .52 & .28 \\
\hline & $\mathrm{Z2}$ & $0.97 \pm 0.93$ & $1.25 \pm 1.16$ & .38 & $1.09 \pm 0.82$ & $1.31 \pm 1.18$ & .57 & $1.09 \pm 1.12$ & $1.13 \pm 0.98$ & .71 & .72 & .88 \\
\hline & $\mathrm{Z3}$ & $0.63 \pm 0.79$ & $0.47 \pm 0.80$ & .33 & $0.34 \pm 0.55^{*}$ & $0.72 \pm 0.77 \mathrm{~d}$ & .03 & $0.28 \pm 0.52$ & $0.28 \pm 0.46$ & .84 & .15 & .04 \\
\hline & $\mathrm{Z4}$ & $1.03 \pm 0.97 b$ & $1.16 \pm 1.02$ & .64 & $1.28 \pm 1.08 \mathrm{~b}$ & $1.34 \pm 1.12$ & .87 & $2.03 \pm 1.49^{*}$ & $1.31 \pm 1.26$ & .04 & .01 & .83 \\
\hline & $\mathrm{Z5}$ & $1.22 \pm 1.18$ & $1.09 \pm 1.09 \mathrm{~d}$ & .71 & $1.81 \pm 1.55$ & $1.34 \pm 1.49$ & .14 & $1.69 \pm 1.28$ & $1.91 \pm 1.33$ & .44 & .20 & .03 \\
\hline & Z6 & $0.63 \pm 0.75$ & $0.97 \pm 0.97 \mathrm{~cd}$ & .16 & $0.72 \pm 0.81$ & $0.38 \pm 0.61$ & .08 & $0.34 \pm 0.60$ & $0.34 \pm 0.79$ & .53 & .10 & .00 \\
\hline & Other & $0.66 \pm 0.97$ & $0.72 \pm 0.81$ & .50 & $0.44 \pm 0.67$ & $0.47 \pm 0.72$ & .99 & $0.19 \pm 0.40$ & $0.28 \pm 0.52$ & .51 & .06 & .05 \\
\hline \multirow[t]{6}{*}{ Outcome } & Goal & $2.31 \pm 1.47$ & $1.84 \pm 1.25$ & .19 & $2.44 \pm 1.16$ & $2.09 \pm 1.12$ & .31 & $2.44 \pm 1.56^{*}$ & $1.41 \pm 1.21$ & .01 & .90 & .06 \\
\hline & Saved & $2.25 \pm 1.63$ & $2.38 \pm 1.21$ & .73 & $2.03 \pm 1.38$ & $2.78 \pm 1.93$ & .13 & $2.78 \pm 1.64$ & $2.69 \pm 1.75$ & .76 & .19 & .78 \\
\hline & Out & $0.66 \pm 0.70$ & $1.00 \pm 0.88$ & .10 & $1.09 \pm 1.09$ & $0.84 \pm 0.99$ & .36 & $0.91 \pm 0.86$ & $1.25 \pm 0.95$ & .14 & .29 & .10 \\
\hline & Post & $0.88 \pm 0.79 b$ & $0.91 \pm 0.93$ & .95 & $1.03 \pm 1.06 \mathrm{~b}$ & $0.78 \pm 0.91$ & .36 & $0.50 \pm 0.92 *$ & $1.03 \pm 1.00$ & .01 & .03 & .56 \\
\hline & Blocked & $0.34 \pm 0.70$ & $0.53 \pm 0.76$ & .20 & $0.44 \pm 0.67$ & $0.47 \pm 0.72$ & .99 & $0.16 \pm 0.37$ & $0.25 \pm 0.51$ & .49 & .14 & .24 \\
\hline & Rejected & $0.03 \pm 0.18$ & $0.00 \pm 0.00$ & .32 & $0.06 \pm 0.35$ & $0.06 \pm 0.25$ & .58 & $0.06 \pm 0.25$ & $0.00 \pm 0.00$ & .15 & .78 & .13 \\
\hline
\end{tabular}

Note: $*=$ different from losers of the same tournament;

$\mathrm{a}, \mathrm{b}=$ different from 2013, and 2014 winning teams, respectively;

$\mathrm{c}, \mathrm{d}=$ different from 2013 and 2014 losing teams, respectively;

$U=$ Mann Whitney $U$ p-value for match outcome in each tournament;

$\chi^{2}$ Win. $=$ Kruskall Wallis p-value for winning teams' comparison between tournaments

$\chi_{2}$ Los. $=$ Kruskall Wallis p-value for losing teams' comparison between tournaments. 
Menescardi, C.; Tessitore, A.; Estevan, I.; Condello, G., \& Lupo, C. (2018). Analysis of shots in relation to the outcome in elite women's water polo matches. RICYDE. Revista internacional de ciencias del deporte, 51(14), 84-95. https://doi.org/10.5232/ricyde2018.05107

\section{Discussion}

This study investigated the shot performance of elite female water polo players, considering eight variables (play situation, offensive arrangement, defensive arrangement, goalkeeper position, player position, type of shot, goal zone, and outcome) and match outcome (winner or loser) during three international women tournaments (i.e., the 2012 Olympic Games, 2013 FINA World League, and 2014 FINA World League). The review of the current literature showed that this is one of the first studies to analyse technical and tactical shot performance variables in elite women's matches to discover possible patterns associated with the winning. Moreover, this is the first study that included Olympic players for this type of data, and the results allow us to make inferences to other competitions played at the elite level.

The main finding of the current study was that no differences between winner and loser teams emerged in the number of shots performed dependent on play situations, offensive and defensive arrangement, goalkeeper position and player position in any of the tournaments analysed. Although similar results were reported by Lupo et al. (2011), who found no differences according to the match outcome, other studies (Escalante et al., 2013; Lupo et al., $2012 \mathrm{~b}$ ) have reported that winning teams perform more counterattacks than losing ones, from which it can be speculated that there is an association with competitive level. The absence of differences between winners and losers in the present study could be explained by the high level of teams analysed (elite), independent of the match outcome. Therefore, further studies involving balanced and unbalanced teams (Lupo et al., 2012a, 2014) could clarify the existence of a possible pattern in play situations linked to the match victory.

With regard to the previous action, no differences were found in the first two tournaments considering match outcome. However, in the 2014 World League, winners performed more shots after displacement than the loser teams. It seems that, after having defined their final arrangement, winner teams usually perform a displacement to the opponents' goal (e.g., P2 swim to post) to create an opportunity to score, where most of the shots performed are patdowns (classified as 'others' in the current observational tool). This situation highlights the high ability of winner teams, whose players are able to occupy free spaces, find the free player, and shoot for the goals at the opportune moment (Özkol et al., 2013).

Regarding goal zones, if we consider that Z3 (the bottom centre position) as an unfavourable zone to shoot to if the goalkeeper is centred, this could explain why teams that shot a higher number to this zone tended to lose the game. However, further studies could analyse a combination of three factors: i) the zone where the shot ends; ii) the position of the goalkeeper; and iii) the player position to determine the accuracy of the shot in each situation. In line with the study of Özkol et al. (2013), Z4 (bottom right corner) is one of the preferred zones to shoot to, which could be due to the right laterality of the majority of players. In our study, the winning teams of the FINA World League 2014 tournament tended to perform more shots to this zone than the losing teams. It seems that the bottom corners are favourable zones to target, as the goalkeeper cannot cover this area effectively and must trust their defenders to block shots made close to the posts (Özkol et al., 2013). However, while winning teams target corners and tended to score a goal, the losing teams often hit the post and did not score. In these sense, the physical preparation and training experience also effect the shooting efficiency and the decisions made by the players and teams (Özkol et al., 2013).

With regard to winners' comparisons, no differences were found between shots delivered during even situations, giving evidence for a similar playing style of winner teams during the different tournaments. However, differences between tournaments emerged for the number of shots performed in power play and counterattack situations. During the Olympic Games, 
Menescardi, C.; Tessitore, A.; Estevan, I.; Condello, G., \& Lupo, C. (2018). Analysis of shots in relation to the outcome in elite women's water polo matches. RICYDE. Revista internacional de ciencias del deporte, 51(14), 84-95. https://doi.org/10.5232/ricyde2018.05107

more shots were performed in power play situations than in the 2013 and 2014 World League tournaments, as well as a higher number of shots during counterattacks were registered in the 2014 World League when compared with the 2012 Olympic Games. Therefore, it could be speculated that, during the most important competitions (i.e., Olympic Games) teams tend to limit their opponents' counterattacks during defence actions, and with the aim of causing their opponents to make exclusion fouls during offensive actions, and then use their centre forward to play the advantage (Lupo et al., 2012b). This tactic is associated with the highest rate of goal scoring (Lupo et al., 2010, 2012a,b, 2014). In that sense, forward players should therefore train to develop their passing speed to capitalize on advantages awarded and score a goal (Escalante et al., 2013). On the other hand, it seems that winners were awarded more advantages for counterattacking actions over time, and accordingly, took fewer shots from 'other offensive arrangement' (linked to counterattacks) in 2012 than in the other tournaments. Considering that counterattack is expected to be associated to anticipation, reaction time, and swimming speed of the offensive player who carried it out, coaches should develop strategies to take possession of the ball more quickly and swim to the opponents' goal to take advantage of this situation if defensive players are not able to defend them (Lupo et al., 2011, 2012a, 2014).

Continuing with the winners' comparisons and regarding the defensive arrangement, our results show that more shots were performed by winners with a defence in zone 1-2 in the 2012 tournament than in the other competitions, while the opposite trend was found for the defensive zone 2-3-4 arrangement. These results are in line with Lupo et al. (2014), who stated that zonal defence (e.g., zone 1-2 or zone 2-3-4) is used more by winning teams. Therefore, choosing zone 1-2 or zone 2-3-4 defence could be the best strategy for defending teams for covering P6 and best shooters, forcing attacking teams to shoot from a less favourable distance or using less skilled players. However, more studies are needed to analyse defensive arrangements to identify a victory pattern linked to this parameter. In addition, more shots with bounce were performed by winners in the first two tournaments (2012 and 2013) than in the last (2014). Although a previous study (Özkol et al., 2013) reported that the elimination of corners following a defender's bounce could affect the occurrence of shots performed by a team, a rule change preventing this was effected in 2005, and an eventual relationship with the results of this study focused on 2012-2014 water polo competitions resulted quite difficult. Similarly, the interpretation of shots performed from P5, and ending in Z4 or hitting the posts was difficult. Authors and readers should be cautious in interpreting these results.

Among losing teams, more shots were performed in power play situations in the 2012 Olympic Games than in the other less important competitions. Therefore, it could be speculated that the most important water polo competition is characterized by forcing exclusion fouls to be made by the opposing team, and the consequent playing of a superiority action (Lupo et al., 2012b) than the other less important competitions, regardless of match outcome.

Considering defensive arrangements, more shots were performed by loser teams during opponents' pressing defence in the 2012 Olympics and fewer in zone 2-3-4 when compared with the other tournaments; more shots were performed against a zone 4-5 defence when compared with the 2014 World League. In particular, pressing play could be associated with the reduction in the number of shots performed by the opponents' shot, confirming previous findings reported for elite water polo losing teams (Lupo et al., 2012a, 2014). Conversely, zonal defences, which could be associated with a higher degree of the opponent centre forward marking, seemed to characterize the FINA World League competitions. 
Menescardi, C.; Tessitore, A.; Estevan, I.; Condello, G., \& Lupo, C. (2018). Analysis of shots in relation to the outcome in elite women's water polo matches. RICYDE. Revista internacional de ciencias del deporte, 51(14), 84-95. https://doi.org/10.5232/ricyde2018.05107

In line with the winner teams' results, fewer shots with bounce were performed in the 2014 World League than in the other tournaments (in 2012 and 2013) also by losing teams. However, despite a potential reference to the rule change regarding defender and goalkeeper bounce (Özkol et al., 2013), no clear interpretation can be provided. Finally, considering the zones where the shot ended, more shots to Z3 were used in the 2013 World League than in the 2014 competition, fewer to Z5 in the 2012 Olympic Games than the 2014 competition, and more shots to Z6 in the 2012 than in the other tournaments. These results suggest an improvement of goal zone choice in 2014, because shots to Z3 are easily saved by the goalkeeper who is normally in a centred position. In addition, considering that no significant difference was reported over time in loser teams for shots hitting the post or off target, the preference to shoot up to the goal corners instead of over goalkeepers' head seems to be due to the higher number of shots ending in Z5 (right upper corner) and fewer to Z6 (over goalkeeper's head) in both World League tournaments than in 2012, which makes it more difficult for the goalkeeper to save.

However, the present study is characterized by the limitation of considering teams as winners or losers depending on the phase of the championship. In particular, it should be noted that winners of one phase of the championship could be a loser in the next phase, and then similar patterns could be repeated throughout championships. Therefore, future studies should specifically consider different phases of a championship to highlight those playing patterns that are related to the team's progress towards the final of the tournament. In addition, the data analysis was performed on a quarter-per-quarter basis, assuming similar teams' behaviour throughout quarters in line of previous studies (e.g., D'Auria \& Gabbet, 2008). Future studies should analyse the quarter effect on the match, which could help to explain whether differences were due to a specific quarter.

\section{Conclusions}

Despite the limitations of the current analysis, this study offers information about the shots performed during elite women matches, which coaches could use to develop effective training programmes and create play strategies to win future matches. In particular, the current study has the following conclusions: (i) a similar playing style characterizes the 2012 and 2013 tournaments independently of the match outcome; (ii) in the most recent international water polo competition (i.e., the 2014 FINA World League), winning teams performed more shots after displacement, more shots ending to zone 4 and scored more goals (and fewer shots against posts) than losing teams, highlighting a higher ability to find a free player, to create team opportunities and to score a goal, especially by means of a shot to a corner zone; (iii) winning and losing teams' behaviours changed over time: winning teams performed more counterattacks as time passed, and losing teams tended to perform more power play situations, whereas, regardless of match outcome, teams usually opted for a more zonal defence in the most recent competition, probably to limit the action of the more effective centre forward players.

\section{References}

Argudo, F. M.; Arias, J. L., \& Ruiz, E. (2009). Influencia de coger el primer balón sobre el marcador parcial y final durante el Campeonato de Europa de Waterpolo masculino de 2006. Kronos, 14(8), 131-138.

Argudo, F. M.; Garcia, P.; Alonso, J. I., \& Ruiz, E. (2007a). Diferencias de los valores de eficacia en desigualdad numérica temporal simple entre equipos perdedores en waterpolo masculino y femenino. Motricidad. European Journal of Human Movement, 18(1), 153-162. 
Menescardi, C.; Tessitore, A.; Estevan, I.; Condello, G., \& Lupo, C. (2018). Analysis of shots in relation to the outcome in elite women's water polo matches. RICYDE. Revista internacional de ciencias del deporte, 51(14), 84-95. https://doi.org/10.5232/ricyde2018.05107

Argudo, F. M.; Garcia, P.; Alonso, J. I., \& Ruiz, E. (2007b). Influence of the efficacy values in counterattack and defensive adjustment on the condition of winner and loser in male and female water polo. International Journal of Performance Analysis in Sport, 7(2), 81- 91.

Botonis, P. G.; Toubekis, A. G., \& Platanou, T. I. (2015). Physiological Responses of Water-Polo Players under Different Tactical Strategies. Journal of Sports Science and Medicine, 14(1), 84-90.

Camerino, O. F.; Chaverri, J.; Anguera, M. T., \& Jonsson, G. K. (2012). Dynamics of the game in soccer: Detection of T-patterns. European Journal of Sport Science, 12(3), 216-224. https://doi.org/10.1080/17461391.2011.566362

Escalante, Y.; Saavedra, J. M.; Mansilla, M., \& Tella, V. (2011). Discriminatory power of water polo game-related statistics at the 2008 Olympic Games. Journal of Sports Sciences, 29(3), 291-298. https://doi.org/10.1080/02640414.2010.532230

D'Auria, S. \& Gabbet, T. (2008). A Time-Motion Analysis of International Women's Water Polo Match Play. International Journal of Sports Physiology and Performance, 3(3), 305-319. https://doi.org/10.1123/ijspp.3.3.305

Escalante, Y.; Saavedra, J. M.; Tella, V.; Mansilla, M.; García-Hermoso, A., \& Domínguez, A. M. (2013). Differences and discriminatory power of water polo gamerelated statistics in men in international Championships and their relationship with the phase of the competition. Journal of Strength and Conditioning Research, 27(4), 893901. https://doi.org/10.1519/JSC.0b013e318260ed85

Escalante, Y.; Saavedra, J. M.; Tella, V.; Mansilla, M.; García-Hermoso, A., \& Dominguez, A. M. (2012). Water polo game-related statistics in Women's International Championships: Differences and discriminatory power. Journal of Sports Science and Medicine, 11(3), 475-482.

Garcia, P.; Argudo, F. M., \& Alonso, J. I. (2012). Waterpolo: sistemas tácticos de juego en desigualdad numérica temporal simple con posesión. Movimiento Humano, 3(1), 45-59.

Gómez, M. A.; DelaSerna, A.; Lupo, C., \& Sampaio, J. (2014). Effects of Situational Variables and Starting Quarter Score in the outcome of elite women's water polo game quarters. International Journal of Performance Analysis in Sport, 14(1), 73-83.

Gómez, M. A.; DelaSerna, A.; Lupo, C., \& Sampaio, J. (2016). Effects of Game Location, Quality of Opposition and Starting Quarter Score in the outcome of elite water polo quarters. Journal of Strength and Conditioning Research, 30(4), 1014-1020. https://doi.org/10.1519/JSC.0b013e3182aa5f59

Hernández-Mendo, A.; López-López, J. A.; Castellano, J.; Morales, V., \& Pastrana, J. L. (2012). HOISAN 1.2: Programa informático para uso en Metodología Observacional. Cuadernos de Psicología del Deporte, 12(1), 55-78. https://doi.org/10.4321/S1578-84232012000100006

Lloret, M. (1998). Waterpolo: Técnica, táctica y estrategia. Madrid: Gymnos.

Lupo, C.; Capranica, L.; Cugliari, G.; Gómez, M. A., \& Tessitore, A. (2015). Tactical, swimming activity and heart rate aspects of youth water polo game. The Journal of Sports Medicine and Physical Fitness, 56(9), 997-1006. 
Lupo, C.; Condello, G., \& Tessitore, A. (2012a). Notational analysis of elite men's water polo related to specific margins of victory. Journal of Sports Science and Medicine, $11(3), 516-525$.

Lupo, C.; Condello, G.; Capranica, L., \& Tessitore, A. (2014). Women's water polo World Championships: technical and tactical aspects of winning and losing teams in close and unbalanced games. Journal of Strength and Conditioning Research, 28(1), 210222.

https://doi.org/10.1519/JSC.0b013e3182955d90

Lupo, C.; Minganti, C.; Cortis, C.; Perroni, F.; Capranica, L., \& Tessitore, A. (2012b). Effects of competition level on the centre forward role of men's water polo. Journal of Sports Sciences, 30(9), 889-897. https://doi.org/10.1080/02640414.2012.679673

Lupo, C.; Tessitore, A.; Cortis, C.; Ammendolia, A.; Figura, F., \& Capranica, L. (2009). A physiological, time-motion, and technical comparison of youth water polo and Acquagoal. Journal of Sports Sciences, 27(8), 823-831. https://doi.org/10.1080/02640410902946477

Lupo, C.; Tessitore, A.; Minganti, C., \& Capranica, L. (2010). Notational analysis of elite and sub-elite water polo matches. Journal of Strength and Conditioning Research, 24(1), 223-229. https://doi.org/10.1519/JSC.0b013e3181c27d36

Lupo, C.; Tessitore, A.; Minganti, C.; King, B.; Cortis, C., \& Capranica, L. (2011). Notational analysis of American women's collegiate water polo matches. Journal of Strength and Conditioning Research, 25(3), 753-757. https://doi.org/10.1519/JSC.0b013e3181cc245c

Menescardi, C. (2017). Observational analysis of women water polo players in the Olympic games of London 2012. Revista Actividad Física y Deporte: Ciencia y Profesión, 25(2), 73-83.

Özkol, M. Z.; Turunç, S., \& Dopsaj, M. (2013). Water polo shots notational analysis according to player positions. International Journal of Performance Analysis in Sport, 13(3), 734-749.

Stirn, I., \& Strojnik, V. (2006). Throwing with different kinetic chains. Revista Portuguesa de Ciências do Desporto, 6(Suppl. 2), 98-100.

Takagi, H.; Nishijima, T.; Enomoto, I., \& Stewart, A.M. (2005). Determining factors of game performance in the 2001 world Water Polo Championships. Journal of Human Movement Studies, 49(2), 333-352.

Tucher, G.; de Souza Castro, F. A.; Martins de Quintais Silva, S. D.; Garrido, N.; Gomes Cabral, R., \& Silva, A. J. (2014). Relationship between origin of shot and occurrence of goals in competitive men's water polo matches. Revista Brasileira de Cineantropometria e Desempenho Humano, 16(2), 136-143. 